\title{
FOREIGN LANGUAGES TEACHING IN HIGH SCHOOL BY MEANS OF BLOG TECHNOLOGIES
}

\author{
НАВЧАННЯ ІНОЗЕМНИМ МОВАМ У ВИЩІЙ ШКОЛІ \\ ЗАСОБАМИ БЛОГ-ТЕХНОЛОГІЙ
}

UDC 372.881.111

DOI https://doi.org/10.32843/2663-

$6085 / 2021 / 33-2.26$

\section{Buzhykov R.P.,}

Candidate of Pedagogical Sciences, Associate Professor at the Department of Theory and Practice

of English Translation

Petro Mohyla Black Sea

National University

\section{Donii V.S.,}

Candidate of Philological Sciences, Associate Professor at the Department of Culturology

Separate Division "Mykolaiv Branch

of Kyiv National University

of Culture and Arts"

Boltayeva lu.P.,

Foreign Language Teacher

Private school "Hypanis-EOS"
Our article is devoted to the introduction of blog technologies in the process of teaching foreign languages. The introduction of blog technology in the educational process is reasonable and appropriate. In our opinion, the use of blog technologies in foreign language teaching makes it possible to achieve a certain level of language competencies and improve the acquired knowledge and skills in further professional activities. Blog technologies are considered an interactive space for the implementation of methodological and pedagogical teaching goals, make more effective a system of organization and control of students' work on learning foreign languages; allow modern and interesting organization of classroom work and manage individual work of students; is a resource for creating tasks aimed at the formation and improvement of all productive and reproductive types of speech activity in foreign language classes. It should be noted that these technologies contribute to the intensification of the communication process, high motivation for self-development and understanding of the new material, which makes it appropriate to use them in the process of teaching foreign languages. The information educational environment in higher educational institutions has a positive effect on increasing the motivation of students in the educational process. The use of blog technologies in foreign language classes saturates them with a variety of visual aids, allows providing interdisciplinary links, present educational material in an interactive form and carrying out its further consolidation, practice and control. In addition, a variety of tasks for individual work of students also provide a computerized learning process that allows students to engage in self-education with pleasure, develop critical and objective thinking through familiarization with many solutions to their tasks.

Key words: blog technologies, educational environment, language competence, motivation, individual work.

Наша стаття присвячена питанню впровадження блог-технологій у процес навчання іноземним мовам. Впровадження блогтехнологій в освітній процес $є$ обірунтованим та доцільним. На нашу думку, використання блог-технологій під час навчання іноземним мовам дає можливість досягти певного рівня мовних компетентностей та вдосконалювати набуті знання й навички у подальшій профресійній діяльності. Блог-технології вважаються інтерактивним простором для втілення методичних i педагогічних цілей навчання, роблять ефрективнішою систему організації та контролю роботи студентів з вивчення іноземних мов, дають змогу сучасно й цікаво організовувати аудиторну роботу і керувати самостійною роботою студентів, $\epsilon$ ресурсом для створення завдань, спрямованих на фоорування та вдосконалення всіх продуктивних і репродуктивних видів мовленнєвої діяльності на заняттях із вивчення іноземних мов. Слід зазначити, що ці технології сприяють інтенсифрікації комунікаційного процесу, високій мотиваціи до саморозвитку й розуміння нового матеріалу, що робить доцільним їх застосування в процесі навчання іноземним мовам. Інсоормаційне освітнє середовище у вищих навчальних закладах позитивно позначається на підвищенні мотивації студентів в освітньому процесі. Використання блогтехнологій на заняттях з іноземних мов насичує їх різноманітними наочними засобами навчання, дає змогу забезпечити міжпредметні зв'язки, представити навчальний матеріал в інтерактивній формі та здійснити подальше його закріплення, відпрацювання й контроль. Крім цього, різноманітні завдання для самостійно роботи студентів також передбачають комп'ютеризований процес навчання, що дає студентам змогу займатися самоосвітою із задоволенням, розвивати критичність та об'єктивність мислення через ознайомлення з безліччю рішень поставлених перед ними завдань.

Ключові слова: блог-технології, освітне середовище, мовна компетентність, мотивація, самостійна робота.
General formulation of the problem. The changes taking place in the modern world require new approaches to the selection and presentation of educational content. It is necessary to revise didactic methods and technologies of quality control and effectiveness of training, develop new ways of organizing and optimizing individual work, and seek new forms of organizing extracurricular activities of stu- dents. The active use of innovative communication technologies (ICT) can be of great importance.

A blog is a website the main content of which can be posts, media, or images that are added regularly. A web blog is a social network that is effective in terms of didactics, because the blog can store and classify information in any form, create online communities to discuss issues, monitor the assimilation 
of educational material through online tests, surveys, reviews and discussions [1]. The blog is developed for communication between the author and readers and therefore is acutely social. A great amount of blogs is available for users. The classification criteria for blogs are: the format of the information posted on the blog - media type; genre; technical basis with content features; authorship (teaching; student and collective for conducting discussions on topics).

Blog technologies are considered as one of the examples of the implementation of the information and communication educational environment in the activities of the tutor. According to P.V. Sysoev's definition, blog technologies are considered the technologies of the Web 2.0 service, which allow you to create a personal page or blog, which can be presented in the form of a diary or a journal, open the possibility of recording and broadcasting oral speeches, commenting blog visitors [2].

Analysis of recent studies and publications. The scientific substantiation of the theory of learning by means of blog technologies was introduced in the works of J. Bloch [3], R. Blood [4], A. Kuzu [5], C. Lowe [6], T. Williams [6], W. Richardson [7]. A.V. Filatova [8], S.V. Titova [9], P.V. Sysoev [2], R. Ferdig [10] studied the use of blog technologies as a means of communication and self-expression on the global Internet, but its potential as a means of creating an authentic language environment is needed to be studied by scientists, etc.

Highlighting previously unsolved parts of a common problem. Blog technologies are designed to develop the cognitive and creative activity of students, to help improve the quality of education and the effectiveness of the use of study time, to reduce the amount of time spent by students on reproductive activities in the educational process.

The purpose of the article. The article aims to identify the features of the use of blog technologies in the teaching of foreign languages in high school.

Presentation main material. Consequently, the method of blog technologies using innovative communication technologies is one of the means to achieve the key tasks set in the context of modern education.

The information and educational environment also includes a system of pedagogical technologies that are relevant to the modern educational reality (in particular, the use of blog technologies), which allows developing a complex of educational and didactic classes for teaching foreign languages in accordance with the skills and knowledge of students [11].

According to A.V. Filatova, blog technologies contribute to the most complete solution to the problem of optimizing the organization of educational activities in the study of foreign languages, paying attention to their didactic properties such as ease of use, efficiency of information space, interactivity and multimedia [8].
The following positive features of the use of ICT in the context of teaching a foreign language to create an information educational environment are highlighted:

- the educational process has an increased range of means and forms of education, which largely correspond to the socio-cultural environment of modern students and have a favorable effect on the level of motivational interest of all participants in the educational process;

- using ICT, the tutor always has access to the latest materials and the most relevant information in the field of methods of teaching foreign languages; hence it follows that the methods of teaching a foreign language are constantly being improved, the pedagogical experience is accumulated and implemented, and the exchange of pedagogical technologies is carried out; all this makes the process of learning foreign languages as exciting and extraordinary as possible;

- such innovative forms of work with educational material as virtual conferences, overviewing broadcasts of foreign language and literature contests, taking part in online educational programs, as well as doing homework and demonstrating it using the gadgets (tablet computers, phones, laptops) [12].

Theoretical analysis of recent research has shown that, depending on the purpose of learning and the development of specific speech skills of students, blogs are divided into three types: teacher's blog, students' personal blogs and study group blog. However, foreign language teaching is more often used as an educational online blog created to solve a number of methodological tasks, including: formation of auditory skills and abilities, expansion and enrichment of vocabulary, formation and improvement of grammar skills, development of reading, speaking and writing skills [13].

Although blogs are not often used in the educational process, many tutors are interested in the educational opportunities of Internet diaries. Modern research in the field of pedagogy has proven the importance of social interaction in the teaching process. Many researchers emphasize the importance of the process of constructing knowledge by students. The construction of knowledge is by its nature discursive, based on relationships and communication; therefore, in the process of obtaining and transforming knowledge, students should have real opportunities to publish their works.

For educators, published student work is an opportunity to draw conclusions about how students transform and internalize meanings and strategies learned from social experiences. For students, such a publication is a material for subsequent reflection and analysis, which allows them to turn again to their works and rethink them, thus enriching their learning experience. In addition, such publication provides feedback, which in turn helps students in the process 
of constructing knowledge. The use of blogs in this aspect is very useful as they enable students to make sense of the material being studied and present their understanding. The ability to make comments on posts in blogs helps to obtain feedback and potential support for new ideas, and the ability to include hyperlinks to other resources in the text helps students to understand the relationship and context of knowledge, its construction and development.

Thus, we can conclude that the educational information environment has a positive effect on increasing the motivation of students in the educational process. The use of ICT while studying foreign languages saturates the academic studies with a variety of visual teaching aids, allows you to provide intersubjective connections, present educational material in an interactive form and carry out its consolidation, development and control. In addition, a variety of homework assignments also affect the computerized learning process, which allows students to engage in self-education with joy and interest, develop critical and objective skills of thinking applying diverse solutions to one problem.

Definitely, in our opinion, the use of blog technologies in foreign language classes will increase interest in the learning process; will allow not only educational but also real communication. Motivation of students when using the educational blog is due not only to technological capabilities, but also to the fact that students themselves will manage their learning process, actively seeking the information they need and receiving comments from the tutor.

Blogs have great potential for active and interactive teaching, intense interaction between students and tutors, the development of higher-order thinking skills, and greater flexibility in the teaching process.

Blogs are more powerful than simple discussion forums. They allow students to use different ways of the personal and intellectual development of new concepts in the process of visualization of abstract ideas and interactive engagement. Unlike forums, where all the participants take part in the discussion, blogs give each student the opportunity to have complete control over the published content. Blogs become a virtual space for testing new concepts, which do not need to be correlated with a hierarchically or thematically organized discussion forum.

The blogs are organized according to a linear structure [9]. They are structured by time of creation and publication on the web. At the current stage, blogs can be considered as one of the most popular social services, as they allow site visitors to enter virtual communication with each other, unite students according to their interests, and find something in common with each other.

It is necessary to transfer a student from a passive consumer of knowledge to an active creator of knowledge, who is able to formulate a problem, analyze ways to solve it, find the optimal result and prove its correctness. It should be considered that students' individual work is not just an important form of the educational process, but it should become its basis.

There are various forms of organization of the students' individual work. But it should be admitted that not every individual work is essentially individual. Only well-prepared individual work by the tutor can lead to success. Therefore, it is very important to consider the question of how to prepare students for individual activity and how to organize their individual work so that they have both an interest in work and satisfaction from the result. This issue can be solved by organizing the individual work of trainees using innovative communication technologies.

It would be logical to assume that blog technologies can be used quite effectively for didactic purposes. Linguists highlighting the main advantages of blog technologies in the process of teaching foreign languages, we may observe the following didactic characteristics of blogs:

- openness of the blog for commenting and visiting by all participants;

- the ability to make changes to the content and structure of the blog;

- the ability to express your own author's vision, personal assessment or opinion about current events in the blog space;

- the ability to fill the blog with the necessary multimedia content, which will have a positive impact on the improvement of language competence via text, illustration, video or audio recording [14].

P.V. Sysoev [2] reveals in his research the specifics and effectiveness of the use of blog technologies in the methodology of teaching foreign languages and it is possible to present the following characteristics of blog technologies in the methodology of teaching foreign languages:

- individual blogs are blogs that are owned and maintained solely by one author;

- collective blogs are blogs with multiple authors;

- personal blog - most often such a blog is an analogue of a diary;

- thematic blog - a blog that contains entries devoted mainly to one narrow topic;

- business blog - such blogs are made to promote a product or service; in addition to advertisements, they often contain useful information such as reviews or comments;

- a public blog is a blog that is created for the purpose of internal (with colleagues) and/or external (with clients, with the public) communication;

- a text blog is a classic blog, the main content of which is text articles;

- photoblog - it is a blog consisting of photographs;

- music blog is a blog that contains music; 
- podcast is a blog, the content of which is dictated by the author and laid out in the form of audio files;

- video blog - it is a blog consisting of video files.

Thus, we determined that teaching students to speak a foreign language using blog technologies can be carried out via various types of blogs, in particular with the help of the creation and operation of a teacher's blog, personal student blogs, as well as academic group blog. The orientation towards communication, as well as the use of linguistic means of a foreign language to solve the necessary issues, forms the students' understanding of the importance of learning a foreign language as a means of direct interpersonal communication.

Speaking about the advantages of work using ICT, one should mention its indisputable advantages: the possibility of implementing the principle of individuality, the presence of instant feedback, great opportunities for visual presentation of language material, an objective assessment of the results of students actions, the student's activity due to the interactive form of working with educational material.

Interest in new teaching tools makes it possible to see the educational capabilities of modern hardware and software - laptops, PDAs, wireless systems and virtual learning environments.

Blogs can be used in teaching any discipline. Blogs can serve not only as a means of organizing the teaching process and communication between tutors and students, but also provide students with the opportunity to share their thoughts or additional materials with groupmates.

The use of blogs in teaching has a number of peculiarities, so it is necessary to take time to acquaint students with the concept of blogs, with the goals of their creation, with how blogs are conducted. In addition, it is necessary to develop strict rules for the educational blog that will determine the frequency of posting messages, their volume, the number of hyperlinks, the need to adhere to the topic of discussion. These rules are developed together with the students, and that's why certain prohibitions need to be stipulated: since communication in blogs is an unofficial online communication, students can sometimes use too informal language in their blogs.

First of all, the use of blogs increases interest in the teaching process. The novelty of technology is one of the motivating factors in the teaching process. Students are motivated to use blogs not only because of technology but also because students write about things that are important to them personally. Students manage their own learning process by seeking information actively and receiving comments from other people.

Also, the use of blogs gives students the right to take part in social processes. In the process of blogging, students quickly learn that their posts can be read by more than just tutors and groupmates. Blogs take assignments outside of the teaching process and the tutor-to-student relationship, allowing everyone to evaluate and comment on student's works.

Conclusions. Considering the features of the use of blog technologies in the teaching foreign languages, we concluded that in order to meet the communicative needs of students in various fields of communication, it is more appropriate to use blog technologies that enhance and optimize the learning process. The use of blog technologies in the process of teaching foreign languages provides prospects for further study of the use of other Internet technologies, in particular, podcasts, wikis, e-mails, forums, chats, etc. in the formation of communicative competence of students. With a clear organization and monitoring of teaching foreign languages and using blog technologies will allow students to reveal their creative potential, develop activity, independence and responsibility; together with the tutor to become subjects of educational activity. Blogging allows each student to participate in the discussion, which opens up new perspectives for teaching process. It should be noted that in the nearest future blogs will take a worthy place in teaching a foreign language along with other modern Internet technologies.

\section{REFERENCES:}

1. Сысоев П.В., Евстигнеев М.Н. Технологии WEB 2.0 в создании виртуальной образовательной среды для изучения иностранного языка. Иностранные языки в школе. 2009. № 3. С. 27-31.

2. Сысоев П.В. Блог-технология в обучении иностранному языку. Язык и культура. 2013. № 4. C. 115-127.

3. Bloch J. Abdullah's blogging: A generation 1.5 student enters the blogosphere. Language Learning and Technology. 2007. Vol. 11. № 2. P. 128-141.

4. Blood R. Weblogs: A History and Perspective. Rebecca's Pocket. 2000. URL: http://www.rebeccablood. net/essays/weblog_history.html (last accessed: 10.03.2021).

5. Kuzu A. Views of pre-service teachers on blog use for instruction and social interaction. Turkish Online Journal of Distance Education. 2007. № 8 (2). P. 34-51.

6. Lowe C., Williams T. Moving to the public: Weblogs in the writing classroom. Retrieved September 14, 2007. 2004, July 21. URL: https://conservancy.umn.edu/bitstream/handle/ 11299/172819/Lowe-Williams_Moving\%20to\%20 the \%20Public.pdf?sequence=1\&isAllowed=y ((last accessed: 10.03.2021).

7. Richardson W. Blogs, Wikis, Podcasts, and Other Powerful Web Tools for Classrooms / W. Richardson. Thousand Oaks. California : Corwin Press, 2010. 184 p.

8. Филатова А.В. Оптимизация преподавания иностранных языков посредством блогтехнологий для студентов языковых специальностей вузов : дисс. ... канд. пед. наук : спец. 13.00.02. Москва, 2009. 237 с

9. Титова С.В. Как облагородить учебный процесс: сервисы Web 2.0 в преподавании иностранных 
языков. URL: http://www.ug.ru/archive (дата звернення: 10.03.2021).

10. Ferdig R.E., Trammell K.D.. Content delivery in the "blogosphere". Journal of Educational Technology. 2005. № 1 (4). P. 16-19.

11. Кирилова Г.И. Инорормационные технологии и компьютерные средства в образовании . Educational Technology and Society. 2010. № 4. C. 23-29.

12. Воронина Т.В., Кашицин В.М., Молчанова О.С. Образование в эпоху новых инорорма- ционных технологий. Москва : Просвещение, 2016. $322 \mathrm{c}$.

13. Раицкая Л.К. Дидактические и психологические основы применения технологий Веб 2.0. в высшем профессиональном образовании : монограсрия. Москва : МГОУ, 2011. 173 с.

14. Павельева Т.Ю. Методика развития умений письменной речи средствами социального сервиса блогов : автореф. дисс. ... канд. пед. наук. Красноярск, 2013. 25 с. 